\title{
An Integer Programming Model for Alternative Selection and Planning Stages for Cleaner Production Programs: a Case Study for Greenhouse Gases Reduction
}

\section{- Thanh Van Tran}

- Hai Thanh Le

Institute for Environment and Resources, National University of Ho Chi Minh City, Vietnam

(Bài nhận ngày 30 tháng 06 năm 2016, nhận đăng ngày 06 tháng 07 năm 2016)

\begin{abstract}
The selection of subjects (such as waste stream, process, apparatus, ect.) for improvement and development their alternatives when implementing cleaner production $(\mathrm{CP})$ programs at the company in order to achieve the highest efficiency is a complex and timeconsuming process, especially in case when there are many subjects to be improved, and many alternatives for each subject. The problem in this case is which subject and its respective alternative is to be selected in order to obtain maximal waste reduction objective with minimization cost. To solve this problem, this article proposes an optimization mathematical model to support alternatives selection for $C P$ programs. In this study, an integer programming

model is applied for defining theselection steps of alternatives and setting the implementing plan within CP program. The proposed model is investigated in a real case study at a cassava starch factory in Tay Ninh, Vietnam (where is the most concentrated area of cassava processing in the country) with purpose to propose the measures for reduction of greenhouse gases (GHGs) and electricity consumption. The results show that this model can be considered as a new effective method for alternative $C P$ selection and planning for CP implementation, especially in case of many subjects and alternatives. The solution of this model can be generalized to apply in any cases with unlimited number of subjects and alternatives.
\end{abstract}

Keywords: Goal Programming, Cleaner Production, Industrial Pollution Prevention, Cassava Starch Processing, Decision Support System

\section{INTRODUCTION}

The successful CP programs provide many benefits including operating costs reduction, raw material use reduction, waste reduction and risk reduction to humans and the environment, improving health and occupational safety,

adaptation to environmental protection regulations. Cagno, Trucco [1] analyzed 134 pollution prevention projects and found that savings $31 \%$ of production cost, $33 \%$ of waste and $6 \%$ of raw materials. In Vietnam, the 
companies interested in cleaner production program increase significantly, and the results achieved from implementation of cleaner production programs become more and more obvious. Just for an example of electricity savings potential: in textile industry is $3-57 \%$, in paper industry is $3-25 \%$, and in the beer industry is $40-60 \%$ [2]. However, the successful implementation of $\mathrm{CP}$ program is not really high because of many barriers. Luken [3] when studying on the implemented $\mathrm{CP}$ projects, indicated that the awareness of CP was improved, however, the CP concept had not been known or fully understood by all industrial and service sectors. A more important barrier is the discrepancy between people trained as assessors and the number of assessors who are qualified and experienced enough to actually conduct inplant assessments[3]. Another aspect that may contribute to these problems is that traditional CP only focuses in solutions with attractive financial indices (high IRR, short payback period), while not all CP solutions are economically feasible, and some solutions only reduce pollution and bring other benefits (eg improved company image, or achievement of reduction objective is required by the third party).

Shi, Peng [4] pointed out that for the small and medium enterprises, the top three barriers are lack of economic incentive policies, lack of environmental enforcement, and high initial capital cost. There are also other important barriers such as lack of effective CP assessment (CPA) measures, and the lack of financial service institutions [4], or no knowledge on CPA and CP, poor accounting and internal auditing systems within companies [5], difficult to quantify all the benefits of cleaner production measures [3]. In addition, Cagno, Trucco [1] inferred that the scarce use of systematic techniques and tools that adopted by companies was still in the early stage and was not completely integrated into the management process.
In general, technical barriers are often found in the literature and are cited as a significant barrier to sustainable $\mathrm{CP}$ initiatives. In order to lessen the impact of technique obstacles in the uptake of CP, quality tools [6] and LCA indicators are suggested as tools for CP [7]. Therefore, it can be expected that some benefits of a CP program will be maximized. Silva, Delai [6]The successful CP programs provide many benefits including operating costs reduction, raw material use reduction, waste reduction and risk reduction to humans and the environment, improving health and occupational safety, adaptation to environmental protection regulations. Cagno, Trucco [1] analyzed 134 pollution prevention projects and found that savings $31 \%$ of production cost, $33 \%$ of waste and $6 \%$ of raw materials. In Vietnam, the companies interested in cleaner production program increase significantly, and the results achieved from implementation of cleaner production programs become more and more obvious. Just for an example of electricity savings potential: in textile industry is $3-57 \%$, in paper industry is $3-25 \%$, and in the beer industry is $40-60 \%$ [2]. However, the successfulSilva, Delai [6] after reviewing common barriers of CP programs, proposing a new CP methodology enhanced by a systematic integration of quality tools that helps to overcome the aforementioned problems. The use of these tools can enhance nearly all steps of a CP methodology, namely the planning stage, crucial for the success a CP program. For alternative selection and planning phases in implementation cleaner production programs, Silva, Delai [6] propose to use GUT matrix and $5 \mathrm{~W} 2 \mathrm{H}$ tools. These tools have the advantage of being easy to use but difficult to apply to multi-subjects and each subject has many alternatives. Another limitation of these tools is not considering waste reduction objectives and the budget for innovation to provide the optimal options.

\section{Trang 6}


While, goal programming (GP) is a multicriteria decision making technique, it is traditionally seen as an extension of linear programming to include multiple objectives, expressed by means of the attempted achievement of goal target values for each objective. Goal programming are widely applied in many fields, and normally divided into 16 main groups (such as academic management, agricultural management, energy planning and production, engineering, environmental and waste management ... [8]. Initially, a review conducted on electronic databases shows that 50,400 results with keywords 'goal programming', 1780 results with "goal programming" plus "waste management" and 117 results with "goal programming" plus "waste management" plus "environment management" are obtained in the initial search. None of these articles present a goal programming methodology for implementation of a cleaner production program. Some typical articles related to environmental and waste management field can be found in Chang and Hwang [9], Chakraborty and Linninger [10], Costi, Minciardi [11], Mavrotas [12] and Ghobadi, Darestani [13]. In particular, Mavrotas [12] suggested a GP model for pollution reduction in order to define Best Available Techniques -BAT necessary for typical industrial sectors in Athens, Greece. For municipal waste management, a research of Costi, Minciardi [11] proposed a GP model to support the decision makers in planning and selection of waste treatment measures which satisfied the requirement of environmentallyfriendly criterions. Chang and Hwang [9] recommended an optimal model for waste minimization, optimal cost in selecting the heating system at the chemical factory. Chakraborty and Linninger [10] proposed the design method of waste treatment systemfollowing the GP method in which the model offered suitable technical options for each waste type and satisfied with given targets. While Ghobadi, Darestani [13] developed general MILP model for minimization the impact of greenhouse gases.

In generally, GP is an effective decision support tool for alternative selection. In this context, this paper proposes an optimization mathematical model based on goal programming into cleaner production methodology for selecting alternatives with objective to reach pollution reduction goal and to satisfy with available financial sources of the company.

\section{PROBLEM DEFINITION}

In general, the $\mathrm{CP}$ program comprises of six steps [14] in which step 2, 3 and 4 select CP options for further implementation, and eliminate the infeasible options in the technical, environmental and economic aspects. The CP assessment practice indicates that for each object which need to be improved, the CP team applies the methods such as brainstorming and benchmarking to identify alternatives (at least two), then analyzes to choose the best for further implementation (to improve this subject). After selecting the improved alternatives for each subject the CP team then develops an implementation plan by prioritizing the $\mathrm{CP}$ options on the basis of multi-criteria method [6, 14]. The selection process of CP alternatives at a traditional CP program is shown in figure 1. Under this approach, the option with highest priority will be implemented first, then the second, the third etc [6]. This approach has the advantage of being easy to assess, however, the decision factors such as reduction targets and resources (usually budget for mitigation) are not involved in the analysis and selection of alternatives. Therefore, the group of selected alternatives from independent selection may not be an optimal choice for the company. 


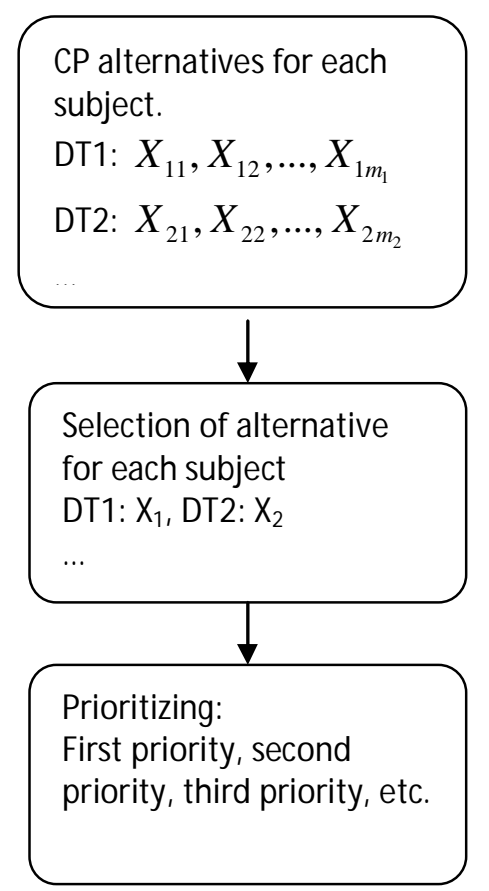

Figure 1. The selection $\mathrm{CP}$ alternatives of a traditional $\mathrm{CP}$ program
To cope with this challenge in the concerned problem, after the CP team identifies the subjects that need to be improved ( $n$ subjects), the CP team continues developing various $\mathrm{CP}$ alternatives - $\mathrm{X}_{\mathrm{ij}}$ for each subject (where: $\mathrm{m}_{\mathrm{i}}$ number of alternatives for subject $\mathrm{i}, \mathrm{j}=1 . . \mathrm{m}_{\mathrm{i}}$, $\mathrm{i}=1 . . \mathrm{n})$. Then, CP team collected information to calculate investment costs $-\mathrm{C}_{\mathrm{ij}}$ and emissions $E_{i j}$ of each alternative. After that, $C P$ team analyses the feasibility of each option then only rejected alternatives that technical or environmental infeasibility. Innovation subjects and their alternatives are shown as table 1.

The main issues to be addressed in $\mathrm{CP}$ alternative selection of CP programs under multi subject and multi alternative conditions, includes determining the numbers and alternatives of subjects with respect to two cases: 1minimization of total cost and adaptation to waste reduction objective; 2 - maximization of waste reduction and adaptation to the budget for innovation.

Table 1. Innovation subjects and their alternatives in general

\begin{tabular}{|c|c|c|c|c|}
\hline \multirow[t]{2}{*}{ Quantity } & \multirow{2}{*}{$\begin{array}{l}\text { Subject } \\
\text { need } \\
\text { innovation }\end{array}$} & \multicolumn{3}{|l|}{$\mathrm{CP}$ alternatives } \\
\hline & & Alternative code & Investment cost & Emission \\
\hline $\mathrm{q}_{1}$ & $\mathrm{DT}_{1}$ & $X_{11}, X_{12}, \ldots, X_{1 m_{1}}$ & $C_{11}, C_{12}, \ldots, C_{1 m_{1}}$ & $E_{11}, E_{12}, \ldots, E_{1 m_{1}}$ \\
\hline $\mathrm{q}_{2}$ & $\mathrm{DT}_{2}$ & $X_{21}, X_{22}, \ldots, X_{2 m_{2}}$ & $C_{21}, C_{22}, \ldots, C_{2 m_{2}}$ & $E_{21}, E_{22}, \ldots, E_{2 m_{2}}$ \\
\hline$\ldots$ & $\ldots$ & $\ldots \ldots$ & & \\
\hline $\mathrm{q}_{\mathrm{i}}$ & $\mathrm{DT}_{\mathrm{i}}$ & $X_{i 1}, X_{i 2}, \ldots, X_{i m_{j}}$ & $C_{i 1}, C_{i 2}, \ldots, C_{i m_{j}}$ & $E_{i 1}, E_{i 2}, \ldots, E_{i m_{j}}$ \\
\hline$\ldots$ & $\ldots$ & $\ldots$ & & \\
\hline $\mathrm{q}_{\mathrm{n}}$ & $\mathrm{DT}_{\mathrm{n}}$ & $X_{n 1}, X_{n 2}, \ldots, X_{n m_{n}}$ & $C_{n 1}, C_{n 2}, \ldots, C_{n m_{n}}$ & $E_{n 1}, E_{n 2}, \ldots, E_{n m_{n}}$ \\
\hline
\end{tabular}

\section{MODEL FORMULATION}

The indices, parameters and variables used to formulate the concerned $\mathrm{CP}$ alternative selection problem are described below.

- $\mathrm{DT}_{\mathrm{i}}$ : group of similar subjects for innovation $\mathrm{i}: \mathrm{i}=1 \ldots \mathrm{n}$

- $\mathrm{q}_{\mathrm{i}}$ : number of similar subjects of $\mathrm{DT}_{\mathrm{i}}$
- $\mathrm{m}_{\mathrm{i}}$ : number of alternatives of subject $\mathrm{DT}_{\mathrm{i}}$

- $\quad X_{i j}$ : CP alternatives of $D T_{i}, j=1 \ldots m_{i}$

- $\mathrm{X}_{\mathrm{i} 0}$ : baseline of $\mathrm{DT}_{\mathrm{i}}$ (without innovation)

- $\quad \mathrm{C}_{\mathrm{ij}}$ : investment cost of $\mathrm{X}_{\mathrm{ij}}$

- $\mathrm{E}_{\mathrm{ij}}$ : emission of $\mathrm{X}_{\mathrm{ij}}$

\section{Trang 8}


- $b_{i j}:$ number of subjects of $\mathrm{DT}_{\mathrm{i}}$ improved by $\mathrm{X}_{\mathrm{ij}}$

- $\mathrm{Z}_{\max }$ : maximization of emission reduction potential

- Z: emission reduction potential

- $\quad$ C: total cost

- $\mathrm{C}_{0}$ : budget for emission reduction

- $\mathrm{Z}_{0}$ : emission reduction objective

\subsection{Objective Functions}

As mentioned in the section 2, there are two cases of $\mathrm{CP}$ alternative selection of $\mathrm{CP}$ programs under multi subject and multi alternative conditions: case 1- minimization of total cost and adaptation to GHG reduction objective; case 2maximization of GHG reduction and adaptation to the budget for innovation.

Objective function of case 1 :

Total investment cost of subjects of $\mathrm{DT}_{\mathrm{i}}$ improved by $X_{i j}=$ number of subjects of $\mathrm{DT}_{\mathrm{i}}$ improved by $X_{i j} x$ investment cost of $X_{i j}$. Thus, the objective function of case 1 can be written as follows.

$\operatorname{MinC}=\sum_{j=1}^{m_{1}} C_{1 j} b_{1 j}+\ldots+\sum_{j=1}^{m_{i}} C_{i j} b_{i j}+\ldots+\sum_{j=1}^{m_{n}} C_{n j} b_{n j}$

Objective function of case 2 :

GHG reduction potential of subjects of $\mathrm{DT}_{\mathrm{i}}$ improved by $\mathrm{X}_{\mathrm{ij}}=$ number of subjects of $\mathrm{DT}_{\mathrm{i}}$ improved by $\mathrm{X}_{\mathrm{ij}} \mathrm{x}$ (baseline emission of $\mathrm{DT}_{\mathrm{i}}$ emission of $X_{\mathrm{ij}}$ ). Therefore, the objective function of case 2 can be written as follows.

$M a x Z=\sum_{i=1}^{n} E_{i 0}\left(\sum_{j=1}^{m_{q}} b_{i j}\right)-\left(\sum_{j=1}^{m_{1}} E_{1 j} b_{1 j}+\ldots+\sum_{j=1}^{m_{q}} E_{i j} b_{i j}+\ldots+\sum_{j=1}^{m_{h}} E_{n j} b_{r j}\right)$

\subsection{Constraints}

Constraint of case 1:

The objective of waste reduction is $Z_{0}$. Thus, total GHG reduction potential is not less than $Z_{0}$.
Constraint of GHG reduction potential can be formulated as follows.

$Z_{0} \leq \sum_{i=1}^{n}\left(E_{i 0} \sum_{j=1}^{m_{i}} b_{i j}\right)-\left(\sum_{j=1}^{m_{1}} E_{1 j} b_{1 j}+\ldots+\sum_{j=1}^{m_{i}} E_{i j} b_{i j}+\ldots+\sum_{j=1}^{m_{h}} E_{n j} b_{n j}\right)$

Constraint of case 2:

The budget of waste reduction is $\mathrm{C}_{\mathrm{o}}$. Thus, total investment cost must be less than $C_{o}$. Constraint of investment cost can be formulated as follows.

$$
C_{0} \geq \sum_{j=1}^{m_{1}} C_{1 j} b_{1 j}+\ldots+\sum_{j=1}^{m_{i}} C_{i j} b_{i j}+\ldots+\sum_{j=1}^{m_{n}} C_{n j} b_{n j}
$$

\subsection{Decision Variables Constraints}

$b_{i j}$ is the non-negative integer variable. The total number of the selected alternatives of each group $\left(\mathrm{DT}_{\mathrm{i}}\right)$ does not exceed the number of subjects of $\mathrm{DT}_{\mathrm{i}}$. The following constraints are related to these restrictions on the decision variables.

$$
\begin{aligned}
& b_{i j} \in Z^{+} \\
& 0 \leq \sum_{j=1}^{m_{i}} b_{i j} \leq q_{i}
\end{aligned}
$$

In case of $\mathrm{q}_{\mathrm{i}}$ is 1 for any $\mathrm{i}$ so that $\mathrm{b}_{\mathrm{ij}}=\{0,1\}$. Thus, the proposed model can be called the binary programming model (a particular case of integer programming).

\section{CASE STUDY}

\section{Case study description}

In this section, the validity of the developed CP alternative selection model under multisubject and multi-alternative conditions is investigated via the data withdrawn from the considered case study. The cassava starch manufacturer firm A (Huu Duc's cassava starch 
production factory) located in Tay Ninh province, Vietnam is a starch factory with 70 tons of starch per day. This firm is a modern cassava starch factory, the cassava starch production process begins with washing of harvested roots, rasping of washed roots by the rasper, extracting by a series of extractors, concentrating the slurry by separators, dewatering the slurry by a centrifuge and dryingthe starch cake by a flash dryer. At this production capacity, around 350 ton fresh roots are consumed; the conversion ratio of root and starch is therefore around from 5: 1. The water consumption of starch production is estimated to be $12 \mathrm{~m}^{3}$ per ton starch and electricity consumption is $200 \mathrm{kWh}$ per ton starch (equivalent to $720 \mathrm{MJ}$ per ton of starch).

However, the average electricity consumption in Vietnam is about $608 \mathrm{MJ}$ per ton starch production [15]. In Thai cassava starch production, electricity consumption is from 320 to $929 \mathrm{MJ}$ per ton starch [16]. Literature review shows that firm $A$ is higher electricity consumption per ton starch than average consumption of other studies. The reasons may come from a poor control on technology process (there are no proper quality and environmental management systems following the international standards) and the backward technology when comparing with Thailand technology. Most of motors/apparatuses of the firm are made in Vietnam, there are likely not comprehensive and are practically innovated from the handicraft technology, therefore, one of the main reasons of the firm A is standard electric motor system use. Thus, replacing standard electric motors by high efficiency electric motors is necessary and this measure is one of the best available techniques [17]. To illustrate the successfulness of the proposed model, this paper applies this model as support tool to alternative selection for replacing standard electric motors by high efficiency electric motors.

\section{Case study method}

There are 5 typical steps: (1) - inventory of all existing motors at the factory together with main parameters such as capacity, operation time,...; (2) - Classifying the motors having similar nature into groups; (3) - Calculating the waste emission of the motors based on the consumed electricity and emission coefficient; (4) - Proposing the alternatives for motors, calculating the emission and cost for each alternative; (5) - Setting the program for transferring the mathematical formulas at section 3 into Lingo language, and the model is resolved by using this language.

\section{Results}

The firm A has 168 electric motors with output power range $0.75 \mathrm{kw}-200 \mathrm{kw}$ that are divided into 4 and 6 pole motor. In this study, $\mathrm{CO}_{2}$ is used as an environmental indicator, $\mathrm{CO}_{2}$ emission factor for electricity in Vietnam is $0.5657 \mathrm{~kg} \mathrm{CO}_{2 \text { equivalent }}$ per Kwh [18]. The alternatives are gotten from database of high efficiency electric motors of motor manufacturers such as ABB, SIEMENS, Brook Crompton. Table 2 is an example of the selection of alternatives. Similarly, alternatives for all 168 electric motors are chosen. Then all electric motors are divided into 29 groups $(\mathrm{N}=29)$, each group comprises subjects (motors) that similar power, emissions and alternatives. Table 3 is an example of one group. All alternatives of each group and their properties are described as Table 4 and Table 5.

\section{Trang 10}


Table 2. Alternatives for 4 poles, $22 \mathrm{kw}$ electric motor

\begin{tabular}{|c|l|l|c|c|c|c|c|}
\hline No. & Manufacturer & Model & Power & $\begin{array}{c}\text { Number } \\
\text { of poles }\end{array}$ & $\begin{array}{c}\text { Efficiency } \\
(\%)\end{array}$ & $\begin{array}{c}\text { Efficiency } \\
\text { class (IE) }\end{array}$ & $\begin{array}{c}\text { Cost } \\
(\text { VND) }\end{array}$ \\
\hline 1 & ABB & $\begin{array}{l}\text { M3BP 180- } \\
\text { MLB 4 }\end{array}$ & 22 & 4 & 92.3 & IE2 & $73,335,815$ \\
\hline 2 & ABB & $\begin{array}{l}\text { M3BP 180- } \\
\text { MLB 4 }\end{array}$ & 22 & 4 & 93.3 & IE3 & $75,023,609$ \\
\hline 3 & $\begin{array}{l}\text { Brook } \\
\text { Crompton }\end{array}$ & $\begin{array}{l}\text { WU- } \\
\text { DA180LJ }\end{array}$ & 22 & 4 & 91.6 & IE2 & $71,072,523$ \\
\hline
\end{tabular}

Table 3. Alternatives and their properties of an example group

\begin{tabular}{|l|l|l|c|r|}
\hline \multicolumn{1}{|c|}{ Alternative } & Sign & \multicolumn{1}{|c|}{ Description } & $\begin{array}{c}\text { Emission, } \\
\mathrm{kgCO}_{2} / \text { day }\end{array}$ & $\begin{array}{c}\text { Investment cost, } \\
\text { VND }\end{array}$ \\
\hline $\begin{array}{l}\text { Baseline - } \\
\text { without } \\
\text { innovation }\end{array}$ & $\mathrm{X}_{10}$ & $\begin{array}{l}\text { DT1 group: P=4kw, 6 poles, } \\
\text { operation time: 15 hrs/day }\end{array}$ & 41.7 & 0 \\
\hline Option 1 & $\mathrm{X}_{11}$ & ABB-M3BP 132 SMC 6 & 39.98 & $26,101,370$ \\
\hline Option 2 & $\mathrm{X}_{12}$ & ABB-M3BP 132 SMF 6 & 39.1 & $29,595,815$ \\
\hline Option 3 & $\mathrm{X}_{13}$ & $\begin{array}{l}\text { Brook Crompton-WU- } \\
\text { DA132MMX }\end{array}$ & 40.12 & $26,933,209$ \\
\hline
\end{tabular}

Table 4. Emission values of all options and their alternatives

\begin{tabular}{|c|c|r|r|r|r|}
\hline Quantity, q & Group & Option $0\left(\mathrm{X}_{\mathrm{i} 0}\right)$ & Option 1 $\left(\mathrm{X}_{\mathrm{i} 1}\right)$ & Option 2 $\left(\mathrm{X}_{\mathrm{i} 2}\right)$ & \multicolumn{1}{c|}{ Option 3 $\left(\mathrm{X}_{\mathrm{i} 3}\right)$} \\
\hline 3 & $\mathrm{DT}_{1}$ & $12,509.34$ & $11,993.64$ & $11,731.11$ & $12,036.17$ \\
\hline 6 & $\mathrm{DT}_{2}$ & $7,026.89$ & $6,519.71$ & $6,459.55$ & $6,643.45$ \\
\hline 27 & $\mathrm{DT}_{3}$ & $12,253.43$ & $11,731.11$ & $11,492.78$ & $11,758.20$ \\
\hline 8 & $\mathrm{DT}_{4}$ & $16,530.19$ & $15,731.54$ & $15,556.75$ & $15,910.31$ \\
\hline 4 & $\mathrm{DT}_{5}$ & $300,130.23$ & $294,449.53$ & $293,523.58$ & $293,523.58$ \\
\hline 10 & $\mathrm{DT}_{6}$ & $62,296.22$ & $60,676.38$ & $60,026.05$ & $61,140.07$ \\
\hline 1 & $\mathrm{DT}_{7}$ & $541,627.66$ & $532,562.76$ & $530,343.75$ & $524,876.29$ \\
\hline 3 & $\mathrm{DT}_{8}$ & $246,353.23$ & $241,930.83$ & $240,660.19$ & $237,664.42$ \\
\hline 1 & $\mathrm{DT}_{9}$ & $106,188.33$ & $100,844.81$ & $99,250.84$ & $99,776.54$ \\
\hline 9 & $\mathrm{DT}_{10}$ & $152,020.36$ & $148,789.32$ & $147,070.12$ & $146,915.79$ \\
\hline 13 & $\mathrm{DT}_{11}$ & $3,733.62$ & $3,349.54$ & $3,329.63$ & $3,440.07$ \\
\hline 4 & $\mathrm{DT}_{12}$ & $43,049.32$ & $41,777.63$ & $41,236.23$ & $42,146.52$ \\
\hline 6 & $\mathrm{DT}_{13}$ & $152,020.36$ & $148,316.47$ & $146,761.79$ & $146,915.79$ \\
\hline 8 & $\mathrm{DT}_{14}$ & $2,727.48$ & $2,425.97$ & $2,419.82$ & $2,515.46$ \\
\hline
\end{tabular}


Saience\&Tedndogy Developmert, Vd 19, Nb.M12016

\begin{tabular}{|r|r|r|r|r|r|}
\hline 9 & $\mathrm{DT}_{15}$ & $22,200.44$ & $21,380.04$ & $21,119.88$ & $21,524.66$ \\
\hline 3 & $\mathrm{DT}_{16}$ & $84,200.11$ & $81,941.52$ & $80,899.89$ & $81,766.06$ \\
\hline 16 & $\mathrm{DT}_{17}$ & $4,946.21$ & $4,529.63$ & $4,476.52$ & $4,611.68$ \\
\hline 5 & $\mathrm{DT}_{18}$ & $2,648.04$ & $2,357.08$ & $2,314.23$ & $2,398.54$ \\
\hline 2 & $\mathrm{DT}_{19}$ & $205,958.74$ & $202,035.71$ & $200,972.37$ & $198,465.44$ \\
\hline 1 & $\mathrm{DT}_{20}$ & $60,414.56$ & $60,676.38$ & $60,026.05$ & $61,140.07$ \\
\hline 3 & $\mathrm{DT}_{21}$ & $124,922.85$ & $121,996.01$ & $120,330.09$ & $120,965.42$ \\
\hline 1 & $\mathrm{DT}_{22}$ & $434,226.01$ & $426,050.21$ & $425,160.75$ & $425,160.75$ \\
\hline 12 & $\mathrm{DT}_{23}$ & $31,965.92$ & $30,975.83$ & $30,371.10$ & $31,182.80$ \\
\hline 1 & $\mathrm{DT}_{24}$ & $134,720.18$ & $131,106.44$ & $129,439.83$ & $130,825.70$ \\
\hline 4 & $\mathrm{DT}_{25}$ & $68,878.92$ & $66,844.20$ & $65,977.97$ & $67,434.44$ \\
\hline 3 & $\mathrm{DT}_{26}$ & $7,913.94$ & $7,247.40$ & $7,162.44$ & $7,378.70$ \\
\hline 1 & $\mathrm{DT}_{27}$ & $329,533.98$ & $323,257.14$ & $321,555.79$ & $317,544.70$ \\
\hline 3 & $\mathrm{DT}_{28}$ & $4,236.87$ & $3,771.33$ & $3,702.76$ & $3,837.66$ \\
\hline 1 & $\mathrm{DT}_{29}$ & $99,673.95$ & $97,082.21$ & $96,041.67$ & $97,824.10$ \\
\hline
\end{tabular}

Table 5- Cost of alternatives of all options

\begin{tabular}{|c|r|r|r|r|}
\hline Group & Option $0\left(\mathrm{X}_{\mathrm{i} 0}\right)$ & Option $1\left(\mathrm{X}_{\mathrm{i} 1}\right)$ & Option $2\left(\mathrm{X}_{\mathrm{i} 2}\right)$ & \multicolumn{1}{c|}{ Option $3\left(\mathrm{X}_{\mathrm{i} 3}\right)$} \\
\hline $\mathrm{DT}_{1}$ & 0 & $26,101,370$ & $29,595,815$ & $26,933,209$ \\
\hline $\mathrm{DT}_{2}$ & 0 & $12,646,565$ & $14,001,554$ & $12,090,319$ \\
\hline $\mathrm{DT}_{3}$ & 0 & $17,139,424$ & $18,518,185$ & $17,067,292$ \\
\hline DT $_{4}$ & 0 & $21,347,022$ & $22,155,261$ & $20,452,987$ \\
\hline DT $_{5}$ & 0 & $304,230,717$ & $308,628,489$ & $327,717,195$ \\
\hline DT $_{6}$ & 0 & $73,335,815$ & $75,023,609$ & $71,072,523$ \\
\hline DT $_{7}$ & 0 & $467,067,130$ & $496,258,825$ & $517,463,217$ \\
\hline DT $_{8}$ & 0 & $186,299,119$ & $195,641,413$ & $205,791,945$ \\
\hline DT $_{9}$ & 0 & $85,982,380$ & $92,139,261$ & $87,587,946$ \\
\hline DT $_{10}$ & 0 & $126,418,109$ & $131,647,891$ & $131,838,989$ \\
\hline DT $_{11}$ & 0 & $9,342,293$ & $9,651,326$ & $9,381,763$ \\
\hline DT $_{12}$ & 0 & $48,827,152$ & $50,728,891$ & $48,171,678$ \\
\hline DT $_{13}$ & 0 & $118,407,032$ & $124,349,967$ & $121,783,473$ \\
\hline DT $_{14}$ & 0 & $6,133,109$ & $7,606,957$ & $6,368,494$ \\
\hline DT $_{15}$ & 0 & $28,026,880$ & $29,714,674$ & $27,793,176$ \\
\hline DT $_{16}$ & 0 & $69,342,163$ & $71,695,565$ & $71,709,034$ \\
\hline DT $_{17}$ & 0 & $10,340,707$ & $10,816,141$ & $10,363,614$ \\
\hline
\end{tabular}

\section{Trang 12}


TAP̈G' PHAḊTREÅNKHSON TAR̈19, SOÁM 2016

\begin{tabular}{|l|l|r|r|r|}
\hline $\mathrm{DT}_{18}$ & 0 & $7,488,098$ & $7,963,533$ & $7,756,629$ \\
\hline $\mathrm{DT}_{19}$ & 0 & $152,852,282$ & $165,926,739$ & $174,864,913$ \\
\hline $\mathrm{DT}_{20}$ & 0 & $73,335,815$ & $75,023,609$ & $71,072,523$ \\
\hline $\mathrm{DT}_{21}$ & 0 & $99,865,076$ & $111,204,196$ & $105,938,417$ \\
\hline $\mathrm{DT}_{22}$ & 0 & $362,732,967$ & $427,368,326$ & $448,501,402$ \\
\hline $\mathrm{DT}_{23}$ & 0 & $36,869,967$ & $40,031,609$ & $34,574,724$ \\
\hline $\mathrm{DT}_{24}$ & 0 & $69,342,163$ & $71,695,565$ & $71,709,034$ \\
\hline $\mathrm{DT}_{25}$ & 0 & $48,827,152$ & $50,728,891$ & $48,171,678$ \\
\hline $\mathrm{DT}_{26}$ & 0 & $10,340,707$ & $10,816,141$ & $10,363,614$ \\
\hline $\mathrm{DT}_{27}$ & 0 & $152,852,282$ & $165,926,739$ & $174,864,913$ \\
\hline $\mathrm{DT}_{28}$ & 0 & $7,488,098$ & $7,963,533$ & $7,756,629$ \\
\hline $\mathrm{DT}_{29}$ & 0 & $73,335,815$ & $75,023,609$ & $71,072,523$ \\
\hline
\end{tabular}

A total of 29 groups with 168 subjects can be replaced and each subject has three alternatives. With a large number of subjects and alternatives, it consumes a lot of time to solve by manual. Therefore, to analyze the performance of the proposed model and the interactive solution method, the model is coded and solved by LINGO 9.0 optimization software. As mention in section 3, the proposed model has two cases. However, they are similarity to each other. So in this paper, the case 1 is used in performance testing with different reduction objective $\mathrm{Z}_{0} . \mathrm{Z}_{0}$ is calculated by formulation:

$$
\mathrm{Z}_{0}=\mathrm{a} \% \mathrm{Z}_{\max }
$$

Whereas, $\mathrm{a}=0$ to $100 \% ; \mathrm{Z}_{\max }$ is maximum emission reduction potential of all subjects. $Z_{\max }$ can be calculated as follows.

$$
Z_{\max }=\sum_{i=1}^{n=29} q_{i}\left(E_{i 0}-\operatorname{Min}_{j=1 \rightarrow m_{i}} E_{i j}\right)
$$

With $\mathrm{a}=5 \%, 10 \%, 50 \%$ and $100 \%$, the results are reported in Table 6 .

Table 6. The summary of results regarding different levels

\begin{tabular}{|c|c|c|c|c|c|}
\hline \multirow{2}{*}{ Group } & \multirow{2}{*}{$\begin{array}{c}\text { Quantity, } \\
\text { item }\end{array}$} & \multicolumn{4}{|c|}{ Number of selected alternatives } \\
\cline { 3 - 6 } & 3 & $\mathrm{a}=5 \%$ & $\mathrm{a}=10 \%$ & $\mathrm{a}=50 \%$ & $\mathrm{a}=100 \%$ \\
\hline $\mathrm{DT}_{1}$ & 6 & 0 & 0 & 0 & $3 \mathrm{X}_{12}$ \\
\hline $\mathrm{DT}_{2}$ & 6 & 0 & 0 & $1 \mathrm{X}_{22}$ & $6 \mathrm{X}_{22}$ \\
\hline $\mathrm{DT}_{3}$ & 27 & 0 & 0 & $8 \mathrm{X}_{32}$ & $2 \mathrm{X}_{32}$ \\
\hline $\mathrm{DT}_{4}$ & 8 & 0 & 0 & 0 & $8 \mathrm{X}_{42}$ \\
\hline $\mathrm{DT}_{5}$ & 4 & 0 & 0 & 0 & $4 \mathrm{X}_{52}$ \\
\hline $\mathrm{DT}_{6}$ & 10 & 0 & 0 & 0 & $10 \mathrm{X}_{62}$ \\
\hline $\mathrm{DT}_{7}$ & 1 & & & & $1 \mathrm{X}_{73}$ \\
\hline
\end{tabular}




\begin{tabular}{|c|c|c|c|c|c|}
\hline $\mathrm{DT}_{8}$ & 3 & 0 & 0 & $3 \mathrm{X}_{83}$ & $3 \mathrm{X}_{83}$ \\
\hline $\mathrm{DT}_{9}$ & 1 & $1 \mathrm{X}_{92}$ & $1 \mathrm{X}_{92}$ & $1 \mathrm{X}_{92}$ & $1 \mathrm{X}_{92}$ \\
\hline $\mathrm{DT}_{10}$ & 9 & 0 & 0 & 0 & $9 X_{103}$ \\
\hline $\mathrm{DT}_{11}$ & 13 & 0 & 0 & $2 X_{111}+11 X_{112}$ & $13 X_{112}$ \\
\hline $\mathrm{DT}_{12}$ & 4 & 0 & 0 & 0 & $4 X_{122}$ \\
\hline $\mathrm{DT}_{13}$ & 6 & 0 & 0 & $6 X_{132}$ & $6 X_{132}$ \\
\hline $\mathrm{DT}_{14}$ & 8 & 0 & $2 X_{141}$ & $8 X_{141}$ & $8 X_{142}$ \\
\hline $\mathrm{DT}_{15}$ & 9 & 0 & 0 & 0 & $9 X_{152}$ \\
\hline $\mathrm{DT}_{16}$ & 3 & 0 & 0 & $3 X_{162}$ & $3 X_{162}$ \\
\hline $\mathrm{DT}_{17}$ & 16 & 0 & 0 & $16 X_{172}$ & $16 X_{172}$ \\
\hline $\mathrm{DT}_{18}$ & 5 & 0 & $1 \mathrm{X}_{182}$ & $3 X_{182}$ & $5 X_{182}$ \\
\hline $\mathrm{DT}_{19}$ & 2 & 0 & 0 & $2 X_{193}$ & $2 X_{193}$ \\
\hline $\mathrm{DT}_{20}$ & 1 & 0 & 0 & 0 & $1 X_{202}$ \\
\hline $\mathrm{DT}_{21}$ & 3 & 0 & 0 & $3 X_{212}$ & $3 X_{212}$ \\
\hline $\mathrm{DT}_{22}$ & 1 & 0 & 0 & 0 & $1 X_{222}$ \\
\hline $\mathrm{DT}_{23}$ & 12 & 0 & 0 & 0 & $12 X_{232}$ \\
\hline $\mathrm{DT}_{24}$ & 1 & $1 X_{242}$ & $1 X_{242}$ & $1 X_{242}$ & $1 X_{242}$ \\
\hline $\mathrm{DT}_{25}$ & 4 & $1 X_{252}$ & $2 X_{252}$ & $4 X_{252}$ & $4 X_{252}$ \\
\hline $\mathrm{DT}_{26}$ & 3 & $1 X_{262}$ & $3 X_{262}$ & $3 X_{262}$ & $3 X_{262}$ \\
\hline $\mathrm{DT}_{27}$ & 1 & 0 & $1 X_{273}$ & $1 X_{273}$ & $1 X_{273}$ \\
\hline $\mathrm{DT}_{28}$ & 3 & $1 X_{281}+2 X_{282}$ & $3 X_{282}$ & $3 X_{282}$ & $3 X_{282}$ \\
\hline $\mathrm{DT}_{29}$ & 1 & 0 & 0 & $1 X_{292}$ & $1 X_{292}$ \\
\hline $\begin{array}{l}\text { Optimal } \\
\text { cost, VND }\end{array}$ & & $248,795,000$ & $516,726,000$ & $3,737,726,000$ & $9,325,994,000$ \\
\hline $\begin{array}{l}\text { reduction, } \\
\mathrm{kg} \mathrm{CO}_{2} \text { per } \\
\text { year }\end{array}$ & & 17,404 & 34,802 & 173,967 & 347,934 \\
\hline
\end{tabular}

If the emission reduction goal is $5 \%, 10 \%$, and $50 \%$ of $\mathrm{Z}_{\max }$, the investment cost of these cases are 249 million VND, 518 million VND and 3,738 million VND. The budget used for improvement at the factory is estimated about 3-4 bill. VND/year, thus, the target " $50 \%$ reduction compared with maximal emission reduction norm" is suited with the condition at the company (According to the item 10, section 1, degree $\mathrm{Nr} 78 / 2014 /$ TT-BTC dated on 18/6/2014 of the Ministry of Finance, the company could take maximally $10 \%$ of the profit (tax included) for setting up the fund for research and development; The average income (tax included) of the company is about 30-40 bill VND/year, thus the budget leaving for improvement is estimated to be about 3-4 bill VND/year). In case of $\mathrm{a}=100 \%$, results show that maximization of emission reduction potential of the firm $\mathrm{A}$ in case of replacing all standard electric motors is $347,934 \mathrm{~kg} \mathrm{CO}$ per year (equivalent to about

\section{Trang 14}


$700,000 \mathrm{Kwh}$ saving per year) and can reduce the overall electricity by $3,7 \%$ which is close to the previously reported in Europe (2-8\% [17]). To achieve this objective, the minimization of investment cost is 9,325 million VND (1 USD $=21,920$ VND). The cost for replacement standard motors by high efficiency motors is high because the additional initial purchase cost may be $20-30 \%$ or higher for motor greater than 20 $\mathrm{kW}$ or may be $50-100 \%$ higher for motor less than $15 \mathrm{~kW}$, depending on the energy savings category [17]. In cassava starch production, cost of electricity shares $9 \%$ of total production cost[19], so using high efficiency motors can reduce by $0,36 \%$ production cost. This is just a potential of emission reduction by using high efficiency motors, thus, potential reduction and savings also comes from other subjects such as waste water and waste heat recovery, good housekeeping $[16,19]$.

\section{CONCLUSION}

The limited use of systematic techniques and tools is one of the main barriers pointed out in the extant literature. To overcome barriers in case of alternative selection of $\mathrm{CP}$ program under multi-subject and multi-alternative conditions, this study proposes an optimal mathematical model to determine optimal. The effectiveness of the optimization model is investigated through a real case. The result obtained from case study

showed that with given potential budget used for improvement at the factory of $3-4$ bill $\mathrm{VND} /$ year, the factory could reduce $50 \%$ greenhouse gases from electricity through the use of high efficiency motors. Results also indicate that using simple comparison and the weighted scoring method for the selection of subjects for innovation and their cleaner production option can reject other potential alternatives. One way to accomplish this problem, all alternatives should be considered base on the goal of reduction or budget for innovation in order to setting up the best plan for $\mathrm{CP}$ implementation.

Besides considering the goal of emission reduction and the budget in the alternative selection, the firm might be interested in other criteria. This research applies only for the case of greenhouse gases reduction from electricity consumption by using high efficiency motors, therefore, many possible future research directions can be defined in this area.

Acknowledgement: This research is funded by Vietnam National University HoChiMinh City (VNu-HCM) under grant number C2016-24-02. 


\title{
Mô hình quy hoạch nguyên áp dụng cho lựa chọn phương án và lập kế hoạch trong chương trình sản xuất xuất sạch hơn: điển hình cho giảm thiểu khí nhà kính
}

\author{
- Trần Văn Thanh
}

- Lê Thanh Hải

Viện Môi trường và Tài nguyên, Đại học Quốc gia TpHCM

\section{TÓM TÁ̀T}

Lựa chọn đối tuợng (nhu dòng thải, quá trình, thiết bị...) để cái tiến và phát triển các phuơng án thay thế để triển khai trong chuơng trình thưc hiện sản xuất sạch hơn tại nhà máy sao cho đạt hiệu quả tối ưu là một vấn đề khó khăn và phức tap, nhất là trong truờng hơp có nhiều đối tuợng có thể cải tiến và mỗi đối tượng có nhiều phuoong án thay thế. Bài toán đặt ra trong truờng hợp này là đối tuợng nào cần cải tiến và phuong án ứng với mỗi đối tuợng là gì để đạt được muc tiêu giảm thiểu tối đa với chi phí đầu tu thấp nhất. Để khắc phục khó khăn này, bài báo này đề xuất mô hình toán tối uu nhằm hỗ trọ lưa chon phuoong án trong triển khai chuoong trình SXSH. Trong nghiên cứu này mô hình quy

hoạch nguyên được áp dụngtrong buớc phân tích phuoong án thay thế và thiết lập kế hoạch triển khai chuoong trình SXSH. Mô hình đề xuất đã đuoọc áp dụng điển hình vào nhà máy sản xuất tinh bột khoai mì ở Tây Ninh, Việt Nam (noi tập trung nhiều co sở sản xuất tinh bột mì nhất nuớc) để đề xuất giải pháp giảm thiểu khí nhà kính và tiêu thu điện năng. Kết quả cho thấy mô hình này là một phuơng pháp mói, hiệu quả để áp dụng cho quá trình lựa chọn phương án và thiết lập kế hoạch thưc hiện trong SXSH, nhất là trong truờng hợp có nhiều đối tuợng và phuong án thay thế. Cách giải mô hình này có thể tổng quát hoá để áp dụng cho truờng hơp đối tuợng cần cải tiến và phuơng án thay thế với số luợng không hạn chế.

Tù khóa: quy hoạch mục tiêu, sản xuất sạch hơn, ngăn ngùa ô nhiễm công nghiệp, sản xuất tinh bột mì, hệ thống hỗ trợ ra quyết định.

\section{REFERENCES}

[1]. Cagno, E., P. Trucco, and L. Tardini, Cleaner production and profitability: analysis of 134 industrial pollution prevention (P2) project reports. Journal of Cleaner Production 13, 593-605(2005).
[2]. Nhân, T.V., N.T.L. Giang, and N.T. Phương, Tù̀ phổ biến và xúc tiến áp dụng SXSH đến xây dựng mô hình sản xuất và tiêu thu bền vũng (Cleaner production promotion toward sustainable production and consumption model), in Vietnamese, in

Trang 16 
$4^{\text {th }}$ Vietnam national roundtable workshop on sustaintable production and consumption. 2009: Huế city, Viet Nam. p. 10-20.

[3]. Luken, R.A., A programmatic review of UNIDO/UNEP national cleaner production centres. Journal of Cleaner Production. 12, 195-205(2004).

[4]. Shi, H., et al., Barriers to the implementation of cleaner production in Chinese SMEs: government, industry and expert stakeholders' perspectives. Journal of Cleaner Production. 16, 842-852(2008).

[5]. Mitchell, C.L., Beyond barriers: examining root causes behind commonly cited Cleaner Production barriers in Vietnam. Journal of Cleaner Production. 14, 1576-1585(2006).

[6]. Silva, D.A.L., et al., Quality tools applied to Cleaner Production programs: a first approach toward a new methodology. Journal of Cleaner Production. 47, 174187(2013).

[7]. Hong, J. and X. Li, Speeding up cleaner production in China through the improvement of cleaner production audit. Journal of Cleaner Production. 40, 129135(2013).

[8]. Jones, D.F. and M. Tamiz, Chapter 3 - Goal programming in the period 1990-2000, in Multiple criteria optimization. 2002, International Series in Operations Research \& Management Science p. 129-170.

[9]. Chang, C.-t. and J.-R. Hwang, A multiobjective programming approach to waste minimization the utility systems chemical processes. Chemical Enoineerin 9 Science. 51(16), 3965 -3965(1996).

[10].Chakraborty, A. and A.A. Linninger, PlantWide Waste Management. 1. Synthesis and
Multiobjective Design. Ind. Eng. Chem. Res. 41, 4591 4604(2002).

[11].Costi, P., et al., An environmentally sustainable decision model for urban solid waste management. Waste Management. 24, 277-295(2004).

[12].Mavrotas, G., An integrated approach for the selection of Best Available Techniques (BAT) for the industries in the greater Athens area using multi-objective combinatorial optimization. Energy Economics 29, 953-973(2007).

[13].Ghobadi, A., S.A. Darestani, and K. Shahroudi, Impact of Closed-Loop Supply Chains on Reducing Carbon Emission and Gaining Competitive Advantage: NSGA-II and MOPSO Solutions. Indian Journal of Science and Technology. 8(35)(2015).

[14]. VNCPC, Mini-guide to Cleaner Production. 2000.

[15].CPI and VNCPC, Tài liệu huóng dẫn SXSH trong công nghiệp: ngành sản xuất tinh bột khoai mì (Guideline on cleaner production in cassava starch production), in Vietnamese. 2010: Hà Nội.

[16].Sriroth, K., Cassava Starch Technology: The Thai Experience. Starch/Stärke. 52, 439-449(2000).

[17].European Commission, Reference document on best available techniques for energy efficiency. 2009.

[18].NOCCOP, Emission factor of Vietnam Grid, in Vietnamese, Department of meteorology, hyrology and climate change. 2015.

[19].Chavalparit, O. and M. Ongwandee, Clean technology for the tapioca starch industry in Thailand. Journal of Cleaner Production. 17, 105-110(2009). 